\title{
Acetaminophen effect on reaction speed and lower limbs power
}

\section{Cristian-Cosmin STRAVA1, Alexandra Mihaela RUSU²}

\begin{abstract}
Background:Acetaminophen (also known as Tylenol or Paracetamol) is a very popular drug, that requires no prescription and is usually used as analgesic and antipyretic. A considerable number of previous studies show that acetaminophen has no effects that could alter exercise capacity or performance. Onthe other hand, there are studies sustaining that exercise performance can be improved with acetaminophen through a reduction in perceived pain, and also a reduction of the body heat produced by the muscle contraction.Purpose:The aim of our study was to check if acetaminophen influences reaction speed and power of the lower limbs muscles. Participants and method:For this study we recruited twenty-nine males, aged between 19 and 28 years old. We had two testing sessions for each participant, in the same day (the baseline evaluation, and the second evaluation at half an hour after acetaminophen ingestion).The evaluationsequence was: Body composition evaluation, acoustic-visual reaction test for one leg (left and right), Squad jump on one leg (5 jumps on each foot) and Stiffness test (7 jumps on each foot).Results: Acetaminophen has no significant influence on visual and acoustic reaction time of left or right leg. The Squat Jump test revealeda significant increase of explosive power on left leg (from $10.19 \pm 1.66$ to $10.61 \pm 1.66 \mathrm{~W} / \mathrm{Kg}, \mathrm{p}=0.03)$ and right leg $(10.16 \pm 1.59 \mathrm{~W} / \mathrm{Kg}$ to $10.62 \pm 1.84 \mathrm{~W} / \mathrm{Kg}, \mathrm{p}=0.02)$. Another significant result of our study is the increase of reactive power (obtained during the Stiffness test) after the acetaminophen ingestion (from $16.35 \pm 4.86$ to $17.53 \pm 3.79 \mathrm{~W} / \mathrm{Kg}$ on left leg and from $15.92 \pm 4.2$ to $17.04 \pm 4.26 \mathrm{~W} / \mathrm{Kg}$ on right leg). Conclusions: Acetaminophen ingestion does not influence visual or acoustic reaction time but canimprovethe exercise performance through an increase in both explosive and reactive power of lower limbs.
\end{abstract}

Key words: acetaminophen, power, reaction time

\section{Rezumat}

Introducere: Acetaminofenul (de asemenea, cunoscut ca Tylenol sau Paracetamol) este un medicament foarte popular, care nu necesită prescripție medicală și este de obicei folosit ca analgesic și antipiretic. Un număr considerabil de studii anterioare arată că acetaminofenul nu are efecte care ar putea să modifice capacitatea de effort sau performanța fizică. Pe de altă parte, există studii care susțin că performanța fizică poate fi îmbunătățită consumând acetaminofen, datorită reducerii durerii percepute, precum și datorită reducerii creșterii temperaturii corporale produsă de contracția musculară. Scopul studiului nostru a fost de a verifica dacă acetaminofenul influențează viteza de reacție și puterea musculaturii membrelor inferioare. Participanți și metodă: Pentru acest studio am recrutat 29 subiecți, de sex masculin, cu vârsta cuprinsă între 19 și 28 de ani. Am avut două sesiuni de testări pentrufiecare participant, în aceeași zi. Cea de a doua evaluare s-a realizat la jumătate de oră după ingestia acetaminofenului. Rezultate: Acetaminofenul nu are nici o influență semnificativă asupra timpului si vitezei de reacție vizuale și acustice. Testul Squat Jump dezvăluie o creștere semnificativă a puterii explozive pe membrul inferior stâng

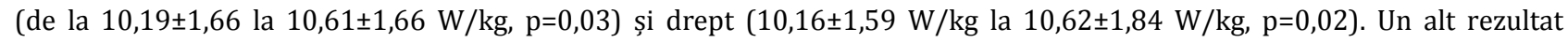
important al studiului nostru este creșterea puterii reactive (obținute în timpul testului Stiffness) după ingestia

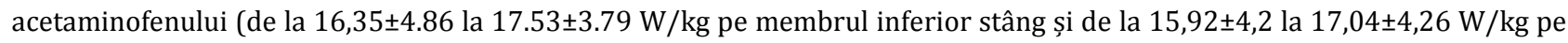
membrul inferior drept). Concluzii: ingestia acetaminofenului nu influențează timpul de reacție vizual sau acustic și în accord cu alte studii, susținem idea că se poate îmbunătăți performanța muscular printr-o creștere a puterii explosive și reactive a membrelor inferioare.

Cuvinte-cheie: acetaminofen, putere, timp de reactie

1 Master degree student, Physical Education and Sports Faculty, West University of Timisoara,e-mail: strava_cosmin@yahoo.com

${ }^{2}$ Assistant professor, PhD, Physical Education and Sports Faculty, West University of Timisoara. 


\section{Introduction}

Acetaminophen (known also as Tylenol or Paracetamol), is a very popular drug, that requires no prescription and is usually used as analgesic and antipyretic [1-3].

Often, in sports field, the contraction-induced muscle injury (muscle soreness, inflammation, and dysfunction) is treated with nonsteroidal antiinflammatory drugs and/or analgesics like acetaminophen. The majority of recent studies failedthough to demonstrate a beneficial effect of nonsteroidal anti-inflammatory drugs or analgesics in these cases, [4-8] and very few studies reported a reduction in muscle soreness and muscle dysfunction $[9,10]$.

A considerable number of previous studies show that acetaminophen has no effects that could alter exercise capacity or performance and likewise exercise has no influence on the pharmacokinetics of acetaminophen. Besides the small antiinflammatory action and the analgesic effect, acetaminophen has no other effects that might modify performance or exercise capacity [11-13].

Onthe other hand, there are studies sustaining that exercise performance can be improved with acetaminophen through a reduction in perceived pain, and also adecrease of the body heat produced by the muscle contraction (heat that is progressively lowering exercise performance) [1417].

A recent study (2014) demonstrate that an acute dose of acetaminophen can determine a significant reductionin core temperature, skinandbody temperature, as well as in thermal sensation, and so,can significantly improve cycling time to exhaustion in hot conditions [14].

Another study [17] demonstrated that a single dose acetaminophenaccelerate the post-effort recovery and help athletes obtaining a better performance after a short break. They verify their result usinga control group that received placebo treatment. The subjects in the placebo group had a longer recovery time and a lower performance at thesubsequent running test.

Based on the conclusions of the previously presented studies we wanted to check if acetaminophen might influence other components of exercise performance; so wedecided to test its effects on reaction speed, power and stiffness of the lower limbs muscles.

\section{Material and methods}

For this study we recruited twenty-nine males, aged between 19 and 28 years old. All the subjects had an average activity level (recreationally active). None of the subjects was chronically consuming acetaminophen,other analgesics or antiinflammatory drugs. Before the inclusion in the study group, all participants were questioned about health conditions that can make acetaminophen ingestion unsafe.

The subjects were informed about the testing protocol and procedures but not on the study hypothesis and they signed an informed consent form.

We had a two testing sessions for each participant, in the same day.The initial evaluation was performed without acetaminophen administration, and the second one, at half an hour after acetaminophen administration. We calculated the dose based on the body weight, and they received $1.4 \mathrm{~g}$ acetaminophen $/ \mathrm{kg}$ body weight.

The sequence of evaluation was: body composition evaluation, acoustic-visual reaction test for one leg (left and right), Squad jump on one leg (5 jumps on each foot) and Stiffness test (7 jumps on each foot).

For the assessment of total body and segmental body composition, we useda segmental multifrequency bioimpedance analyser(InBody 720, South Corea). We recorded the following data: total body water, visceral fat, bone mineral content, total skeletal muscle mass, total body fat, fat percentage, segmental muscle and fat mass [20].

For the acoustic-visual reaction test we used Optojump Next system. We applied a modified test. The subject started in a position with knees bent at $90^{\circ}$, hands on the waist. The foot who executed the test was inside the testing area, and the other outside the perimeter. The subject must raise the foot (bending the knee), as quick as he can, when receiving a visual or acoustic stimulus. Optojump systemrecorded the reaction time [18,21].

Measurement of the lower limbs power was made during a Squat Jump (Sj) test:The subject started in a one leg position, with knee bent at $90^{\circ}$, inside the testing area. Hands remain on hips during the test. 
The subject executes a jump and landed on both feet. He completed the test when he reached five jumps $[18,21]$.

Stiffness Jump (STIFF) test was used to determine muscular reactive force.Inside the testing area, the subject executed seven jumps on one leg without bending the knee. The hands were always on hips $[18,21]$.

\section{Statistical analysis}

We used GraphPad Prism 6 statistical software and the Student's paired $t$ test, to analyse the differences in power, force, stiffness and reaction speed between first and second evaluation (30 minutes after acetaminophen ingestion).

\section{Results}

Our results show that acetaminophen has no significant influence on visual reaction timeof left or right leg $(\mathrm{p}=0.252$ and $\mathrm{p}=0.496)$ and acoustic reaction time $(\mathrm{p}=0.267$ and $\mathrm{p}=0.281)$.

The Squat jump test reveal a significant increase of explosive power on left leg (from $10.19 \pm 1.66$ to $10.61 \pm 1.66 \mathrm{~W} / \mathrm{Kg}, p=0.03)$ and right leg $(10.16 \pm 1.59$ $\mathrm{W} / \mathrm{Kg}$ to $10.62 \pm 1.84 \mathrm{~W} / \mathrm{Kg}, \mathrm{p}=0.02$ ). (Figures 1 and 2).

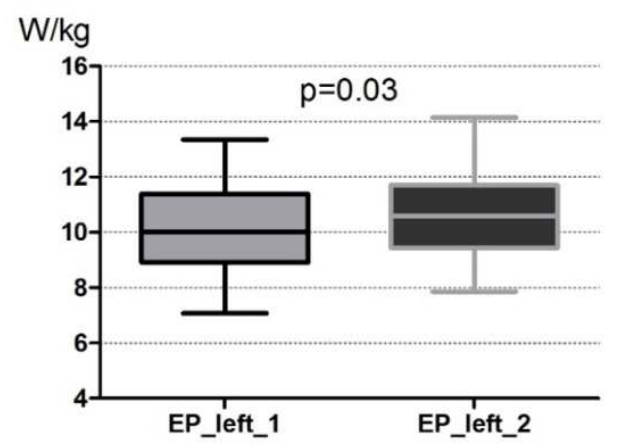

Figure1. Trend of the left leg explosive power after acetaminophen ingestion.

Legend:EP_left_1: Explosive power of the left leg at baseline; EP_left_2: Explosive power of the left leg after 30 minutes of acetaminophen ingestion.

Another significant result of our study is the increase of reactive power (obtained during the Stiffness test) after the acetaminophen ingestion (from $16.35 \pm 4.86$ to $17.53 \pm 3.79 \mathrm{~W} / \mathrm{Kg}$ on left leg and from $15.92 \pm 4.2$ to $17.04 \pm 4.26 \mathrm{~W} / \mathrm{Kg}$ on right leg). (Figures 3 and 4)

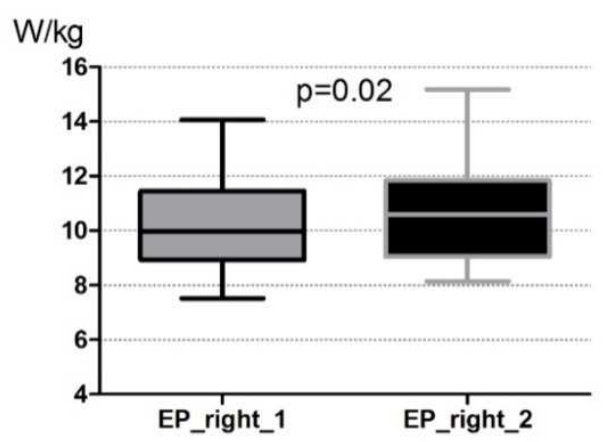

Figure 2.Trend of the right leg explosive power after acetaminophen ingestion

Legend:EP_right_1: Explosive power of the left leg at baseline; EP_right_2: Explosive power of the left leg after 30 minutes of acetaminophen ingestion.

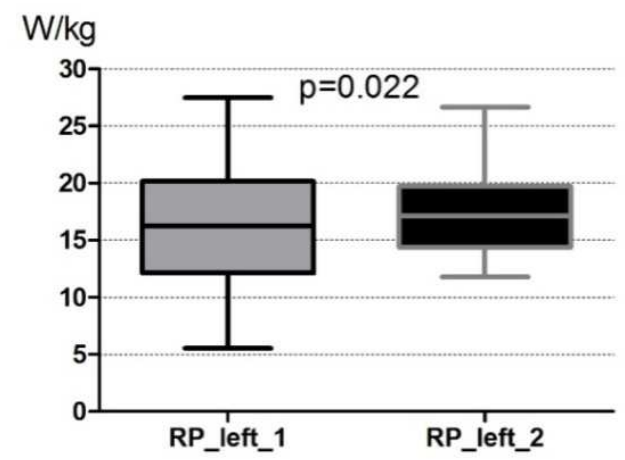

Figure3. Trend of the left leg reactive power after acetaminophen ingestion

Legend:RP_left_1: Reactive power of the left leg at baseline; RP_left_2: Reactive power of the left leg after 30 minutes of acetaminophen ingestion.

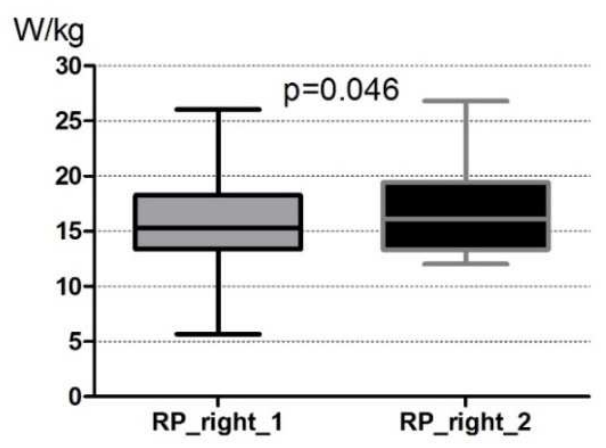

Figure4.Trend of the right leg reactive power after acetaminophen ingestion

Legend:RP_right_1: Reactive power of the left leg at baseline; RP_right_2: Reactive power of the left leg after 30 minutes of acetaminophen ingestion. 


\section{Discussions}

Several studies highlight acetaminophen ingestion benefits on different parametersof exerciseperformance $[1,14]$.

Effects like reduction of perceived pain, increase of the power output were observed in a study which analysed performance during time trialcycling [1]. In our study we noticed an increase in both explosive power (measured during the squat jump test) and the reactivepower output (measured during the Stiffness test).

Post-effort recovery acceleration and performance improvement are also related to acetaminophen consumption [17].

Another study shows that consumption of ibuprofen and acetaminophen, had attenuated the increase in muscle protein synthesis rate, that normally appear 24 hours after high-intensity eccentric resistance exercise.They haven't found other findings of acetaminopheninfluence on skeletal muscle metabolism to discuss verify or explain their results [19].

Acetaminophen can help athletes to enhance lower limbs power, but this approach for performance enhancement can be dangerous.

Using acetaminophen to reduce pain perception during exercise (effect described in some studies) can increase the risk of injury, and can also cause liver, kidney and gastrointestinal problems [1-3, $11]$.

We didn't find in the literature other studies to compare and verify our results, so we think that further studies are needed in order to demonstrate and explain the mechanisms that can be involved in power improvement after acetaminophen ingestion.

\section{Conclusions}

Our study demonstrates that acetaminophen ingestion does not influence visual or acoustic reaction time.In consent with the studies presented above,wesustain the idea that acetaminophen ingestion can lead to increase in exercise performance through an increase in both explosive and reactive power of lower limbs.

\section{References}

1. MaugerA.R., JonesA.M., WilliamsC.A. (2010)Influence of acetaminophen on performance during time trial cycling.Journal of Applied Physiology, Vol. 108 no. 1, p. 98-104.

2. Morgan S., Dorman S.(2004) Paracetamol (acetaminophen) allergy. J Pain Symptom Manage, Vol. 27 no. 2, p. 99-101.

3. Andrade S.E., Martinez C., Walker A.M.(1998) Comparative safety evaluation of non-narcotic analgesics. Journal of Clinical Epidemiology, Vol. 51, no. 12, p. 1357-1365

4. PetersonJ.M. et al. (2003)Ibuprofen and Acetaminophen: Effect on Muscle Inflammation after Eccentric Exercise. Medicine \&amp Science in Sports \&amp Exercise Journal Impact Factor \& Information, Vol. 35, no. 6, p. 892-896.

5. Barlas P., Craig J.A., Robinson J., Walsh D.M., Baxter G.D., Allen J.M. (2000)Managing delayed-onset muscle soreness: lack of effect of selected oral systemic analgesics.Arch Phys Med Rehabil. Vol. 81, No. 7, p. 966-972

6. GrossmanJ.M., ArnoldB.L., PerrinD.H., and KahlerD.M. (1995)Effect of ibuprofen on pain, decreased range of motion, and decreased strength associated with delayed onset muscle soreness of the elbow flexors. Journal of Sport Rehabilitation. Vol. 4, p. 253-263.

7. Pizza F.X.,Cavender D., Stockard A., Baylies H., Beighle A. (1999)Anti-Inflammatory Doses of Ibuprofen: Effect on Neutrophils and Exercise-Induced Muscle Injury. International Journal of Sports Medicine, Vol. 20, p 98-102.

8. Smith L., GeorgeR.T., ChenierT.C.,McCammon M.R., HoumardJ.A., IsraelR.G., HoppmannR.A. and Smith $\mathrm{S}(1995)$ Do over-the-counter analgesics reduce delayed onset muscle soreness and serum creatine kinase values?Sports Medicine, Training and Rehabilitation, Vol. 6, No. 2, p. 81-88.

9. Dudley G. A., Czerkawski J., MeinrodA.,Gillis G., Scarpone M. (1997) Efficacy of naproxen sodium for exercise-induced dysfunction muscle injury and soreness.Clinical Journal of Sport Medicine, Vol. 7, p. 3-10.

10. Hasson S.M, Daniels J.C., Divine J.G., Niebuhr B.R., RichmondS., Stein P.G., Williams J.H. (1993) Effect of ibuprofenuse on musclesoreness, damage, and performance: a preliminaryinvestigation.MedicineandScience in SportsandExercise, Vol. 25, No. 1, p. 9-17.

11. Medicines Compendium (2008). Surrey, UK: Datapharm Communications, [http://emc.medicines.org/uk/].

12. Rossi S. (2008)Paracetamol. Australian MedicinesHandbook. Australian MedicinesHandbook.

13. Sawrymowicz M. (1997)The effect of exercise on thepharmacokinetics of acetaminiphenandacetylsalicylic acid. Ann Acad Med Stetin, Vol. 43, p. 57-66.

14. Alexis R.Mauger, Lee Taylor, Christopher Harding, BenjaminWright, Josh Foster and Paul C. Castle (2014) Acute acetaminophen (paracetamol) ingestion improves time to exhaustion during exercise in the heat. Experimental Physiology, Vol. 99, No.1, p. 164-171.

15. AlonsoJ. G., TellerC. , Signe L.Andersen et al (1999)Influence of body temperature on the development of fatigue during prolonged exercise in the heat.Physiology,Vol. 86 No. 3, p. 1032-1039.

16. Edwards R.H., Hill D.K., Jones D.A. (1975)Heat production and chemical changes during isometric contractions of the human quadriceps muscle.The Journal of Physiology, Vol. 251, p. 303315. 
17. KovaciF., PejaE., GjeraziR.(2014),Paracetamol administration for enhancing recovery and preventing underperformance in athletes. Journal of International Academic Research For Multidisciplinary, Vol. 2, No. 3, p. 351-358.

18. GraurC.,FăgărașSimona-Pia. (2013), Differences in the explosive force of the lower limbs betweenfemale volleyball teams. Palestrica of the third millennium - Civilization and Sport ,Vol. 14, No. 4, p. 288-291.

19. TrappeT.A., WhiteF., LambertE.J. (2002), Effect of ibuprofen and acetaminophen on postexercise muscle protein synthesis. Am J PhysiolEndocrinolMetab, Vol. 282, No. 3, p. 551-556.

\section{Website:}

20. http://inbodyaustralia.com.au/inbody-technology-2/

21. http://www.optojump.com/Applications.aspx 